Uniwersytet Wrocławski

\title{
Wezwanie do dialogu z Innym, czyli Ryszard Kapuścinski na tropie Lévinasa i Tischnera
}

\author{
Appeal for Dialogue with The Other - Ryszard \\ Kapuścinski on the Scent of Lévinas and Tischner
}

\author{
$20 / 2016$ \\ Political Dialogues \\ DOI: http://dx.doi.org/10.12775/DP.2016.029
}

\begin{abstract}
:
Ryszard Kapuscinski is known mostly as a traveler and reporter. There are several publications of his writing. Not many people consider his work from the social and philosophical perspective. Meanwhile, the famous writer created his own concept of co-operation between people, representatives of different cultures. He predicted that this issue has become a significant social problem at the beginning of this century. Kapuściński created timeless studies of revolution, cooperation or policy. $\mathrm{He}$ extracted a lot from Emmanuel Levinas and Józef Tischner. I try to follow his concept showing how he imagine cooperation between people or whole civilizations.
\end{abstract}

Słowa kluczowe: dialog, rozmowa, spotkanie, wielokulturowość, podróż, poznanie

Keywords: dialogue, talk, meeting, multiculturalism, journey, cognition

\section{Wstęp}

Istotnym nurtem twórczości Ryszarda Kapuścińskiego jest jego zainteresowanie drugim człowiekiem. Przejawia się ono przede wszystkim opisywaniem ludzi, których spotykał w czasie swoich podróży. To zaciekawienie, widoczne właściwie w każdym jego utworze, musiało towarzyszyć mu od początków jego reporterskiej pracy, o czym najlepiej zaświadczaja jego wczesne reportaże pisane $z$ Polski. Jednak dopiero od pewnego momentu bohaterami jego pisarstwa stali się Inni, rozumiani jako ludzie innej rasy, przedstawiciele innych wyznań i kultur. Podróżnik dążył do zrozumienia i opisania inności i Innego.

„(...) lubiłem jeździć przygodnymi ciężarówkami, wędrować $z$ koczownikami po pustyni, być gościem chłopów z tropikalnej sawanny. Ich życie jest mozołem, jest udrekka, która znosza jednak ze zdumiewajaca wytrwałościa $i$ pogodą. Nie jest to więc ksiażka o Afryce, lecz o kilku ludziach stamtad, o spotkaniach $z$ nimi, czasie wspólnie spedzonym ${ }^{1}$."

Inny, o którym pisał Kapuściński, jest nam najczęściej odległy, reprezentuje dalekie kultury, rasy czy religie. Jednak przez niezwykle szybko postępujace zmiany widoczne zarówno na mapie świata, jak też w rozwoju technicznym, odległość, jaka nas od niego dzieliła, w przedziwny sposób zmniejszyła się. Co więcej, do historii przeszło już przekona-

1 Kapuściński R., Heban, Warszawa 2003, s. 5. 
nie ludzi Zachodu o nadrzędnej roli ich kultury. Ostatnie dziesięciolecia pokazały, że inne cywilizacje, choć przyjmuja naukowo-techniczne osiagnięcia kręgu europejskiego, to zdecydowanie odrzucaja jego wartości duchowe. Zasadniczym celem Kapuścińskiego było przygotowanie nas, czyli ludzi kultury zachodniej, do spotkania $z$ Innym. Jednocześnie zainteresowaniu ta tematyka towarzyszyła jego troska o los Innego. Inny jest bowiem często człowiekiem ubogim, potrzebujaccym pomocy i wsparcia.

Kapuściński wyraźnie dążył do oswojenia nas $z$ Innym, chciał nas przygotować na spotkanie $z$ nim. $Z$ jednej strony opisywał go i przybliżał, by oswoić nas z nim, z drugiej zaś strony pracował nad stworzeniem własnej metody relacji z Innym, która stopniowo postaram się opisać w niniejszym artykule. Podróżnik chętnie korzystał przy tym $z$ koncepcji stworzonych przez filozofię dialogu. Posadowiona na tragicznych doświadczeniach minionego wieku myśl proponowała odejście od totalizującej ontologii w kierunku etyki. Trafności założeń filozofii dialogu Kapuściński doszukał się w zwrocie ku pojedynczemu człowiekowi, ku jednostce. Pisarz podjał się zadania ożywiania abstrakcyjnego bytu filozoficznego, o którym pisali Emmanuel Lévinas i Józef Tischner przez bezpośredni kontakt i zbliżenie $z$ Innym. Propozycje wskazanych filozofów były dla niego silną inspiracją, co postaram się wykazać w dalszej części pracy.

W swoich tekstach, ale również życiu, Kapuściński starał się podażać za Lévinasem i Tischnerem, którzy nieustannie poszukiwali drogi do Innego, by uwolnić nas od pokusy izolacji, egoizmu i zobojętnienia. Jednocześnie starał się w swoich pracach nie pouczać i nakazywać, ale pobudzać umysły i uczucia, zachęcać czytelników do wspólnej refleksji.
W Podróżach z Herodotem, które uznać można za książkę autobiograficzną, Kapuściński wspominał, że chęć podróżowania towarzyszyła mu od pierwszych wypraw po Polsce śladami listów nadesłanych do redakcji „Sztandaru Młodych", gdzie pracował po ukończeniu studiów. Wewnętrzny niepokój i pragnienie poznania nieznajomego nasilały się, kiedy odwiedzał przygraniczne wioski. Cisza i pustka panujace $\mathrm{w}$ pasie przygranicznym dodatkowo wzmagały jego ciekawość. Nie afiszując się nadmiernie $z$ tymi pragnieniami, poprosił przełożoną o możliwość wyjazdu zagranicę. W okresie, kiedy Polska i cały blok wschodni oddzielone były od świata żelazna kurtyna, możliwości wyjazdu poza tę strefę zdarzały się niezwykle rzadko. Jednak po roku od tej śmiałej prośby, Kapuściński został przez redakcję wysłany do Indii, a później Chin. Zaspokojenie pragnienia przekroczenia granicy obudziło w nim jednak kolejne rozterki. Ogrom i odmienność odwiedzonych kultur przytłoczyły wówczas młodego podróżnika, zawstydziły $z$ powodu jego niewiedzy, nieoczytania i ignorancji. Indie i Chiny były dla Kapuścińskiego odkryciem nowego świata. To nadzwyczajne i fascynujace spotkanie było dla niego wielka lekcja pokory wobec nieznanych krajów. Przekonał się, że poznanie innych kultur wymaga od niego dlugich oraz solidnych przygotowan oraz pracy nad soba.

Spotkanie z Innymi ludźmi, przedstawicielami obcych kultur i światów, stało się jednym $z$ wiodacych elementów twórczości Ryszarda Kapuścińskiego. Namysł nad przebiegiem tego spotkania u progu XXI wieku stał się wręcz uwieńczeniem jego refleksji wynikajacych $z$ kilkudziesięciu lat podróży, obserwowania świata i ludzi oraz przemian zachodzących w tych relacjach.

„Inny” Kapuścińskiego posiada przede wszystkim dwoista naturę. $Z$ jednej 
strony jest człowiekiem, jak każdy z nas, czyli istota o określonym charakterze, trybie życia i przyzwyczajeniach. Z drugiej zaś strony jest on przedstawicielem określonej kultury, nosicielem pewnych cech rasowych, konkretnych wierzeń i przekonań. Te dwie istoty splataja się ze sobą, współżyją i nigdy nie występują oddzielnie. Kapuściński wielokrotnie podkreślał siłę, z jaką oddziałują uprzedzenia rasowe, odruch wartościowania według koloru skóry, przy czym pamiętać należy, że osiemdziesiąt procent mieszkańców ziemi stanowią niebiali.

\section{Historia relacji z Innym}

Niezwykle istotna cechą twórczości Ryszarda Kapuścińskiego jest chęć uświadamiania czytelnikom, że spotkanie $z$ Innym nie musi przebiegać na zasadzie starcia i konfliktu, mimo iż od zarania dziejów ludzkość niechętnie odnosiła się do obcych. Wielkie imperia Persów, Arabów czy Mongołów wyprawiały się poza swoje granice, by podbić i zniewolić sasiednie cywilizacje. Historia odnotowuje też całe społeczeństwa, które zupełnie nie interesowały się światem zewnętrznym. Znakomitym przykładem takiej kultury jest Afryka, której mieszkańcy nigdy nie wyprawiali się za morze, by poznać swoich sąsiadów. Jeszcze dalej poszła cywilizacja chińska, która odgrodziła się murem od reszty ludzkości. Kapuściński wskazywał, iż jedynie Europa od początku swojej historii interesowała się światem zewnętrznym, a poza chęcia panowania nad nim wykazywała także ciekawość względem Innych. Jej najtęższe umysły pragnęły wyłacznie poznania, zrozumienia i zbliżenia $z$ Innymi dażac jednocześnie do utworzenia wspólnoty ludzkiej. Często jednak historia relacji ludzi Zachodu z jej sassiadami przebiegała w sposób gwałtowny i okrutny, okry- wajac Europę wstydem i hańbą na setki lat. Kapuściński wielokrotnie w swoich książkach wypominał naszej cywilizacji nadmierne dążenie do panowania nad światem oraz poczucie wyższości względem Innych. W ksiażce Ten Inny przywołał historię relacji Europy ze światem znajdującym się poza jej granicami. Stosunki te podzielił na cztery zasadnicze etapy, prowadzace od epoki kupców, przez wielkie odkrycia geograficzne, po oświecenie i przełom antropologów, zmierzajace do zwieńczenia tych relacji w postaci filozofii Emmanuela Lévinasa i Józefa Tischnera oraz idei wielokulturowości.

a) Świat opisany przez Herodota.

Pierwszym znanym Europejczykiem, który wyprawił się poza granice swojego kraju, by poznać sassiednie regiony i ich mieszkańców, był grecki historyk Herodot, który choć uznawał nie- Greka za kogoś bełkotliwego, posługujacego się nieznanym mu językiem, to będacego jednak oddzielnym bytem, któremu należni jesteśmy szacunek. Herodot pisał o spotkanych ludziach bez pogardy, nierzadko wskazywał, że pod wieloma względami sa lepsi od Greków. Traktował Innych, jak lustro w którym możemy się sami przeglądać. Podróżnik przeciwstawiał się odgradzaniu od świata, dażenie takie uznawał za słabość i ksenofobię cechujace ludzi słabych, o kompleksie niższości, przerażonych możliwościa przejrzenia się w zwierciadle obcych im kultur. Epoka relacji z Innymi opisana przez Herodota sięga aż do XV wieku. Ludzie wchodzili wtedy w relacje $z$ Innymi w czasie podróży, wypraw posłów lub na szlakach handlowych.

b) Epoka wielkich odkryć geograficznych.

Po tym długim okresie Europa wkroczyła w prawdziwe „wieki ciemne” w relacjach $z$ Innymi. Trwająca kilkaset lat epoka wielkich odkryć geograficznych to czas 
wojen, bezwzględnych mordów i grabieży na ogromna skalę. Rządza korzyści majątkowych, jakie szerokim strumieniem zaczęły napływać na stary kontynent zaślepiły europejska elitę. Zyski czerpano nie tylko $z$ handlu cennymi kruszcami, ale także ludźmi. Obraz Innego, jaki maja w tamtym czasie Europejczycy, przedstawia nagiego dzikusa i poganina, którego można, a nawet należy dyskryminować i poniżać. Okres wielkich odkryć geograficznych wpłynął także w znaczący sposób na postrzeganie naszej rasy przez Innych. Kapuściński wyjaśniał, iż fakt, że przez lata Europa na spotkanie $z$ obcymi wysyłała swoich najgorszych przedstawicieli, ludzi o przeszłości kryminalnej, bandytów i nieudaczników, bo tylko tacy ludzie decydowali się na wyprawę w nieznane za ocean, przesadził o utrwaleniu wzajemnych uprzedzeń i stereotypów ${ }^{2}$.

c) Oświecenie.

Zmianę w relacjach $z$ Innymi przyniosło dopiero Oświecenie. Ryszard Kapuściński, który sam często wspominał, że przed każda wyprawa wiele czasu poświęcał na przygotowanie się do wyjazdu przez lekturę książek na temat regionu, który zamierzał odwiedzić, uważał iż drogę do zmiany postrzegania Innego otworzyła właśnie literatura. Oprócz podróży i pogłębionej refleksji właśnie ten rodzaj poznania uznawał za główne źródło, $z$ którego czerpał wiedzę na temat odwiedzanych stron ${ }^{3}$. Wskazywał przy tym, że niemal cała literatura światowa od Homera po chrześcijański Stary Testament i żydowską Torę jest poświęcona Innym, pobudzajac tym samym umysły do chęci ich poznania i dotarcia do najdalszych i nieznanych zakamarków ziemi. Literatura doby Oświecenia, w tym utwory Da-

2 Kapuściński R., Ten Inny, Warszawa 2006, s. $13,16,21-22$.

3 Kapuściński R., Lapidarium I-III, Warszawa 207, s. 210. niela Defoe, Jonathana Swifta, Jana Jakuba Rousseau, Woltera i wielu innych piętnowały nadużycia wobec przedstawicieli obcych kultur i ras ukazujac, iż niebiały i nie-chrześcijanin, choć od nas niepodobny, również jest człowiekiem. Procesowi temu sprzyjał rozwój literatury podróżniczej.

d) Przełom antropologów.

$\mathrm{Na}$ fali tej zmiany sposobu myślenia ludzi Zachodu narodziła się wówczas nowa gałaź nauk społecznych - antropologia. Odejście od ciasnego europocentryzmu ku wizjom bardziej uniwersalnym umożliwiło rozwój myśli skierowanej ku Innemu. Jej osiagnięcia okazały się zdaniem podróżnika kolejnym po Oświeceniu przełomem w sposobie myślenia Europejczyków o Innych. Choć historia współczesnych antropologów rozpoczęła się od badaczy gabinetowych, to już $\mathrm{w}$ połowie dziewiętnastego wieku w skutek zmiany pozycji antropologii jako nauki, uczeni wyruszyli w teren do zmitologizowanego świata dzikich ${ }^{5}$. Uznali, że tylko dzięki tej taktyce moga poznać Innego w sposób czysty i wolny od obcych wpływów, w jego naturalnym otoczeniu. Odkrycia kolejnych badaczy przeczyły przekonaniu o supremacji europejskiego modelu kultury, otworzyły białym oczy na bogactwo nieznanych im wcześniej kultur, wykazując jednocześnie, iż kultury Innych choć odmienne od europejskiej, także posiadaja własna wartość.

Po Oświeceniu i przełomie antropologów, które, jak wcześniej opisałam, dokonały znaczacych przemian w myśleniu Europejczyków o Innych, nastapiła kolejna zmiana w podejściu do przedstawicieli obcych cywilizacji zainspirowana fi-

4 Kapuściński R., Ten Inny, s. 11, 18.

5 Walczak B., Antropolog jako Inny, Warszawa 2009, s. 20. 
lozofią dialogu. Kapuściński szczególnie cenił dorobek Emmanuela Lévinasa.

\section{Sila dialogu i spotkania}

a) Dialog jako narzędzie porozumienia międzykulturowego.

Autor Hebanu ubolewał, że w dziedzinie filozofii w pierwszej połowie dwudziestego wieku dominowaly ontologia i epistemologia Husserla i Heideggera, zamiast etyki. Uważał, iż właśnie problematyce moralności należało w tym szczególnym momencie w dziejach ludzkości przyznać pierwsze miejsce pośród dziedzin filozofii. Dramatyczne doświadczenia minionego stulecia, $z$ jej tragicznymi dla ludzkości następstwami, powinny w naturalny sposób skierować zainteresowanie filozofów właśnie w kierunku etyki ${ }^{6}$.

Filozofia dialogu zaproponowała reorientację i odejście od problematyki ściśle ontologicznej na rzecz wyeksponowania zagadnień związanych $\mathrm{z}$ człowiekiem, jako osoba samodzielna, unikalna i niewspółmierną. Za jej największą zasługę Kapuściński uważał zainteresowanie jednostka, jako wartością samą w sobie, której przysługuje prawo do egzystencji i artykulacji. Wyraźne stało się również zbliżenie myśli filozoficznej do jednostki, jako bytu odrębnego i niepowtarzalnego. Filozofia dialogu zajmowała czytelne stanowisko $\mathrm{w}$ postmodernistycznym szumie, wielości dźwięków i pomieszaniu języków, podejmując tematy wartości, tożsamości, szacunku oraz poważania Innego ${ }^{7}$.

Współczesny świat utracił wymiar uniwersalistyczny, co oznacza, że wyzbyliśmy się przekonania o istnieniu pierw-

6 Kapuściński R., Ten Inny...,, s.53.

7 Tamże, s. 55- 56. szych zasad bytu i poznania. Przemiany, jakie dokonały się w dwudziestym wieku, o których tak wiele pisał Ryszard Kapuściński, odkryły wielość światów, bezmiar poglądów i idei. Ów pluralizm wkracza obecnie we wszystkie dziedziny życia, począwszy od wymiaru metafizycznego, przez sferę aksjologiczną i wielość wartości, aż po politykę, czego przejawem jest próba zjednoczenia Europy pod sztandarem zachowania wielości kultur, jakie się na nia składaja. Jednocześnie ten pluralizm pozostawia zdezorientowanego człowieka samemu sobie w świecie nieokreśloności, niejasności i różnorodności. Utrata uniwersaliów i absolutyzmów, koniec wielkich teorii, utrata ontologicznej jedności oraz pojawienie się wielu systemów orientacji w świecie stawiaja ludzi przed koniecznościa poszukania porozumienia. Właśnie $\mathrm{w}$ tych przemianach i nowych warunkach dostrzec należy podstawy do dialogu, ale jednocześnie jego konieczność ${ }^{8}$.

Chociaż podróżnik rozumiał dialog jako autonomiczną wartość, co wykażę w dalszej części niniejszej pracy, to najczęściej występował on $\mathrm{u}$ niego w kontekście poszukiwania narzędzi porozumienia międzyludzkiego.

„(..) istota rzeczy jest $w$ ogóle utrzymywanie dialogu. Pytanie o sens dialogu jest pre-pytaniem. Jeżeli przed dialogiem zaczniemy zastanawiać sie, czy on ma sens, to nigdy nie dojdziemy do samego dialogu. Bo wtedy zawsze uznamy, że sa to tak rozbieżne skale wartości, że właściwie nie możemy sie porozumieć. Jednak musimy sie porozumieć, tzn., że warunkiem kontynuowania bytu ludzkości, warunkiem istnienia człowieka na ziemi jest porozumienie, dlatego że ten świat, $w$ którym żyjemy, jest tak naładowany

8 Tamże, s. 19. 
różnymi czynnikami eksplozji, że go bardzo łatwo wysadzić $w$ powietrze $e^{\text {." }}$

Kapuściński uważał, że w warunkach, w jakich znalazł się świat, nie ma innej drogi, niż dialog. Ludzie musza zrozumieć, że wysiłek porozumienia jest koniecznym kryterium dalszego istnienia. Procesy kontaktu kultur sa nieuniknione, zatem należy uczynić wszystko, by na ich styku nie doszło do zderzeń, ale do współpracy ${ }^{10}$. Zadaniem filozofii jest przygotowanie człowieka do życia w wielości. Musi ona raz jeszcze podjać zasadnicze badania, wskazujac przy tym na poznawcze aspekty spotkania międzyludzkiego i przedstawiajac warunki konieczne, aby takie spotkanie zaistniało oraz wskazać wartości, jakie pojawiaja się podczas wystapienia dialogu ${ }^{11}$.

Kapuściński dostrzegał w filozofii Lévinasa przede wszystkim reakcje na doświadczenia ludzkości pierwszej połowy XX wieku, szczególnie na problemy cywilizacji zachodniej, jej przemiany i widoczny, pogłębiajacy się kryzys stosunków międzyludzkich. Podkreślał doniosłość i wagę, ale przede wszystkim potrzebę dociekań żydowskiego filozofa ${ }^{12}$. Cień Holokaustu w istotny sposób zaważył na myśleniu Lévinasa. Filozof w swojej twórczości wielokrotnie krytykował filozofię europejską i jej greckie korzenie jako skoncentrowane wyłacznie na bycie, który przejawia się w wojnie i przemocy. Przez wojnę zmuszano Innych do afirmacji idei całości i jedności ustanawianej przez rozum, religię lub historię. Ideałem filozofii europejskiej od zawsze była Całość i Jedność, a wszelkie działanie

9 Ciołek D. SJ; Oszajca W. SJ: W labiryncie kultur. Wywiad z Ryszardem Kapuścinskim, [w] Przegląd Powszechny nr 12/2004, s. 14.

10 Tamże.

11 Kłoczowski J. A., Filozofia dialogu, Kraków 2005, s. 24.

12 Kapuściński R., Ten Inny..., s. 27, 95. i myślenie nabierało sensu tylko przez skierowanie się ku jakiejś idei wszechogarniającej, której należało się absolutnie podporządkować. Przejawiająca się w ten sposób jedność bytu i myślenia dążyła za wszelką cenę do zredukowania tego co odmienne i różne do tożsamego ${ }^{13}$. Wielkim wyzwaniem dla Lévinasa była myś1 Martina Heideggera, w szczególności jego ontologia. Uważał ją za pierwsza filozofię mocy, władzy i niesprawiedliwości. Nie wchodząc w szczegóły historyczne, nie chcąc również śledzić odpowiednich wątków twórczości czy biografii Heideggera, wskazać należy tu jednak, iż uległ on fascynacji Nazizmem. Lévinas zaś uznał, iż w samej istocie rozważań niemieckiego myśliciela tkwia przesłanki do przemocy i gwałtu. Myśleniu takiemu Lévinas zarzucał strach przed Innym nazywając ja filozofia immanencji, autonomii, albo ateizmu. Filozofia Zachodu odsłaniając Innego i ukazując go jako byt, odbiera mu jego odmienność ${ }^{14}$. Badacz Talmudu uznawał zaś Innego za kogoś, kto nie jest ze mną tożsamy, Kogoś na zewnatrz mnie, kogo zrozumieć w pełni nie jestem w stanie. Jedyna relacja, jaka dopuszcza tu Lévinas jest kontakt, który nie daje się ujać w kategoriach logicznych, ale pomaga jednostce uwolnić się spod panowania zobiektywizowanej całości. Myśliciel stawia sobie za zadanie ukazanie prymatu tego założenia nad filozofią totalności ${ }^{15}$.

b) Krytyka poznania.

Konsekwencją wskazanych powyżej koncepcji ontologii było również ostro

13 Skarga B., Emmanuel Lévinas - metafizyka jako etyka, [w] Filozofia XX wieku. Tom I, Warszawa 2002, s. 118.

14 Levinas E., Odkrywajac egzystencje Husserlem i Heideggerem, Warszawa 2008, s. 198.

15 Skarga B., Emmanuel Lévinas - metafizyka jako etyka..., s. 120. 
krytykowane przez Lévinasa założenie o możliwości poznania Innego. Takie nastawienie stało się według niego w konsekwencji źródłem nadużyć i uzurpacji zarazem rozumu, jak też polityki. Krytyka poznania obecna w twórczości filozofa opiera się przede wszystkim na podważaniu koncepcji zaproponowanych przez Edmunda Husserla oraz Martina Heideggera. Dążenie do odróżnienia relacji twarzą- w- twarz od relacji poznawczej prowadziło rozważania Lévinasa w kierunku uznania tej ostatniej za zastepujaca sam podmiot elementem mediacyjnym ${ }^{16}$. Autor Inaczej niż być lub ponad istota zarzucał Husserlowi i Heideggerowi, iż w swoich teoriach uprzedmiotowili inne Ja i podporządkowywali je Ja poznajacemu, czyniąc je tym samym możliwym do uchwycenia w samym poznaniu. Wchodzac $\mathrm{w}$ relacje poznawcza poznajacy traktuje inne Ja, jak poznawany przedmiot, próbuje zamknąć go w pojęciu. Lévinas proponował, by w miejsce relacji poznawczej przyjąc postawę etyczna wobec Innego. Jej sensem ma być umiejscowienie siebie jako bytu poznającego poniżej bytu poznawanego. Propozycję Lévinasa należy traktować jako dezyderat wyjątkowej dbałości o etyczny charakter relacji z Innym, zachętę do szczególnej staranności o czystość, uczciwość i dobroć w stosunku do niego ${ }^{17}$.

Istnieje wyraźna trudność pogodzenia podejścia filozofa do kwestii poznania, $z$ pragnieniem zbliżenia się do Innego, jakie znajdujemy w twórczości Ryszarda Kapuścińskiego. Już na wstępie odnotować trzeba, iż w żadnym ze swoich utworów Kapuściński nie odnosi się wprost do Lévinasowskiej definicji poznania, co znacznie utrudnia

16 Waligóra M., Etyczny projekt Emmanuela Lévinasa - fenomenologia czy antyfenomenologia?, [w] Fenomenologia nr 6/2008, s. 45.

17 Tamże, s. 37, 51. rozstrzygnięcie, jak on sam rozumiał to zagadnienie. Jednakże wielokrotnie pisał o poznaniu innych światów i jego mieszkańców, siebie zaś nazywał tłumaczem kultur. Jak więc sam rozumiał filozofię Lévinasa $\mathrm{w}$ tym zakresie? Czy już na tym etapie rozważań należałoby odrzucić pełną spójność ich poglądów?

Kapuściński chętnie posługiwał się słowem poznanie. Padało ono wielokrotnie, kiedy pisał o swoich doświadczeniach obcowania wśród obcych mu ludzi, kultur, czy miejsc. Kapuściński reporter starał się znaleźć jak najbliżej rdzennych mieszkańców odwiedzanych terenów, przebywał wśród nich, odseparowując się jednocześnie od grup białych zamieszkujacych okolicę. W Hebanie pisał, że wynają mieszkanie w niebezpiecznej dzielnicy Lagos, które było regularnie okradane, jednak tylko tam mógł przebywać wśród rdzennych mieszkańców miasta, obserwować ich codzienne życie i zmagania ${ }^{18}$. Jednocześnie podkreślał, że wyjście ku Innemu, otwarcie się na niego nie jest dla człowieka postawa naturalna i oczywista, lecz wymaga wysiłku woli i wyrobienia nawyków oraz wykształcenia $^{19}$. Wytyczne te doskonale koresponduja $z$ zarzutami, jakie Lévinas stawiał poznaniu. Poznajacy w relacji $z$ poznawanym najczęściej redukuje go do Tego Samego, a poznanie staje się jedynie rozwijaniem jego własnej tożsamości ${ }^{20}$.

c) Wartość dialogu.

Również Kapuściński ostrzegał przed niebezpieczeństwem ignorowania odmienności i odrębności Innego. Doświadczenia podróży po krajach ubogich i nierozwiniętych dodatkowo kazały mu

18 Kapuściński R., Heban..., s. 117.

19 Kapuściński R., Lapidarium VI, Warszawa 2007, s. 68.

20 Lévinas E., Całość i nieskończoność..., s. 32. 
przestrzegać przed patrzeniem na Innych $z$ wyższościa, protekcjonalnie i lekceważąco. Różnorodność świata jest przecież jego cechą konstytutywna od zarania dziejów ludzkości. Kapuściński zastanawiał się, dlaczego zatem jej zrozumienie i akceptacja napotykaja stały opór ludzkiego umysłu. Ostrzegał też, iż nasz rozum przejawia tendencje apodyktyczne i unifikujące domagając się przy tym uznania wyłącznie własnej kultury i wartości za doskonałe i uniwersalne ${ }^{21}$. Postulował, aby zamiast takiej postawy spróbować zaprzyjaźnić się z Innym. Wymaga to wiele heroizmu i nie jest zadaniem łatwym, gdyż wspomniana różnorodność oznacza również złożoność, sprzeczność, a nawet paradoksalność świata, w którym oprócz dobra znajdziemy także zło. Reporterowi zależało, by ocalić drugiego człowieka w jego wewnętrznym bogactwie zmierzajac zawsze $\mathrm{w}$ kierunku dobra, zrozumienia Innych i pełni ich człowieczeństwa ${ }^{22}$. Służyć miał temu dialog, już nie jako warunek międzykulturowego porozumienia, ale wartość sama w sobie, autonomiczna i niezależna.

Właśnie rozmowie $\mathrm{w}$ głównej mierze poświecone są Podróże z Herodotem, $\mathrm{w}$ których reporter wiele uwagi przeznaczył roli języka i dialogu, jako zasadniczym narzędziom umożliwiającym mu wykonywanie zawodu i zdobywanie wiedzy o świecie. Tylko dzięki nim mógł poznawać odwiedzane kraje, jego mieszkańców, ich doświadczenia, przeżycia i opinie. Rozmowa umożliwiła mu poznanie prawdziwe, oparte na wiedzy źródłowej i niczym niezafałszowanej. Co więcej, książka została pomyślana jako specyficzny dialog Kapuścińskiego z Herodotem. Rozmowa ta powinna być lek-

21 Kapuściński R., Lapidarium V, Warszawa 2007, s. 75 .

22 Kapuściński R., Lapidarium IV..., s. 117. cja pokory nie tylko dla dziennikarzy, ale również dla każdego człowieka. Herodot i Kapuściński sa najlepszymi nauczycielami prawdziwego poznania drugiego człowieka. Przez spotkanie i rozmowę osiagali poznanie wolne od uprzedzeń i stereotypów, dalekie od oceniania i wartościowania.

„Pojąłem, że każdy świat ma własna tajemnicę i że dostęp do niej jest tylko na drodze poznania języka. Bez tego świat ów pozostanie dla nas nieprzenikniony i niepojęty, choćbyśmy spędzili w jego wnętrzu całe lata" ${ }^{23}$.

Słowa Kapuścińskiego, który pisał, iż poznanie bez języka jest niedoskonałe i niepełne współgraja $z$ podobna wizja filozofa dialogu. Polski podróżnik doskonale zdawał sobie sprawę $z$ roli języka, jako narzędzia umożliwiającego rozmowę. Podróżując po świecie widział, iż przychylność Innego zaskarbić można sobie przez bezpośredni kontakt oparty na języku, na rozmowie, na poznaniu bodaj kilku słów ze słownika napotkanych ludów ${ }^{24}$. Waga języka objawiała się jako narzędzie umożliwiające dialog.

Kapuściński zgodnie $z$ założeniami filozofii Lévinasa nigdy nie pytał o Innego, ale pytał jego samego, w chęci poznania zawsze zwracał się bezpośrednio do napotykanego bytu. Mówienie do Innego i każda relacja $z$ nim jako rozmówca poprzedza wszelką ontologię i jest ostateczna relacja $\mathrm{w}$ byciu $^{25}$. Zatem poznanie rozumiane jest przez nich jako zbliżenie się i porozumiewanie możliwe jedynie przez rozmowę, w której Inny występuje nie tylko jako niezależny od nas, ale przede wszystkim równorzędny, jeśli nie nawet ważniejszy. Wydaje mi się, iż wyjaśnieniem różnicy narzucającej się między dą-

23 Kapuściński R., Podróże z Herodotem, Kraków 2007, s. 26.

24 Kapuściński R., Lapidarium VI..., s. 142.

25 Lévinas E., Całość i nieskończoność..., s. 38. 
żeniem Kapuścińskiego do zrozumienia Innego, a negacja poznania u Lévinasa, jest wspólne obu myślicielom odwołanie się do wyższości napotykanego bytu.

Lévinas uważał, iż jedynie w rozmowie nasz rozmówca wchodzi $z$ nami w czysta relację, wyraża się i odsłania nie w zapożyczonym świetle, ale w swojej obiektywności. Rozmowa, o której pisze żydowski filozof, nie może być oczywiście incydentalnym przepływem słów, ale czymś znacznie ważniejszym. W rozmowie moje Ja musi wyjść ku Ja rozmówcy, musi być bytem wobec Innego. Istota tak pojętej rozmowy jest ustanowienie wspólnej przestrzeni pomiędzy rozmówcami. Moja mowa do drugiego oraz słowa, które on do mnie kieruje czynią ten obszar rozmowy naszym wspólnym terenem, w którym możemy się spotkać ${ }^{26}$. Mówić, to zbliżać się i otwierać na Innego przy pełnym zaangażowaniu i bez możliwości uniku. Lévinas podkreślał wagę rozmowy, która nie sprowadza się do wymiany informacji, ale jest warunkiem tej wymiany. Rozmowa nie jest też zwykłym przekazaniem rozmówcy zasobu treści do rozkodowania i interpretacji ${ }^{27}$.

Rozmowie z Innym, zbliżeniu się do niego Lévinas, a za nim Kapuściński przeciwstawiają obojętność wobec drugiego człowieka:

„Jazda tramwajem: najtrudniejsza do zniesienia jest obojętność, nieruchomość, martwota twarzy jadacych ludzi. Nieobecność ich wzroku, brak zainteresowania kimś innym, które zreszta $w$ tej sytuacji może być tylko nietaktem, przejawem zlego wychowania, natrectwem"28.

W swoim wezwaniu Kapuściński wyodrębnia jednostkę, indywidualizuje ja, pokazuje nam, że nie jesteśmy na świe-

26 Kłoczowski J. A., Filozofia dialogu..., s. 79.

27 Lévinas E., Inaczej niż być lub ponad istota, Warszawa 2000, s. 84- 89.

28 Kapuściński R., Lapidarium VI..., s. 76. cie sami, ale otaczaja nas Innymi ludzie, z którymi będziemy się obojętnie mijać, jeśli sami nie wykażemy chęci spotkania.

d) Odpowiedzialność za spotkanie.

Moje spotkanie $z$ Innym przez rozmowę wydarza się w twarzy. Twarz jest etyczną prośba, która jednocześnie wyraża moralny nakaz i zakaz ${ }^{29}$. Przez etyczny dostęp do twarzy filozof chciał powiedzieć, że jawi się ona jako obnażona i bezbronna, zabraniająca nam zabijać. Ów etyczny wymóg każe rozpoznać nędzę drugiego człowieka, wsłuchać się w jego głos i odpowiedzieć na to wezwanie. Przy czym nie moge oczekiwać od Innego żadnej wzajemności. Odpowiedź Innego jest jego sprawa, zaś moja troska ma być moja własna powinnośćc ${ }^{30}$. Kluczowa zaś powinnościa wobec Innego jest odpowiedzialność za niego.

$\mathrm{W}$ książce Ten Inny w kontekście zagadnienia odpowiedzialności wobec drugiego człowieka pojawia się oprócz Lévinasa, także postać polskiego filozofa i księdza katolickiego Józefa Tischnera. Pochodzacy z Łopusznej filozof uważał, że w poczuciu odpowiedzialności wyraża się prawda o człowieku, która wyróżnia go, ale też wiąże ze światem. Jest wartością, której można nadać wymiar odpowiedzialności za kogoś lub wobec kogoś, jednak nie wyplywa to $z$ samej istoty odpowiedzialności. Jeżeli chcemy przeżyć dogłębnie doświadczenie odpowiedzialności musimy zgodzić się na heroizm pozostania sam na sam $z$ wartościami, być sprawiedliwym dla samej sprawiedliwości i wiernym dla samej wierności ${ }^{31}$.

Tischner uważał, że myślenie filozoficzne staje się twórcze dopiero wtedy,

29 Gadacz T., Filozofia Boga $w$ XX wieku..., s. 199

30 Kłoczowski J. A., Filozofia dialogu..., s. 81.

31 Tischner J., Myślenie wedtug wartości, Kraków 2011, s. 49. 
kiedy wyrasta $z$ doświadczenia przebywania $z$ Innymi ludźmi. Jednak owo przebywanie nie może ograniczać się do bycia obok, ale musi brać odpowiedzialność za drugiego człowieka. Podobnie jak myślenie samych dialogików wyrastało z troski o naród żydowski, tak filozofia Tischnera wynikała $z$ problemów polskiej ziemi i próbowała im zaradzić. Na poczatkowym etapie silnie związana była z aksjologia, by w później przybrać postać filozofii dramatu ${ }^{32}$.

Kapuścińskiego $z$ oczywistych względów w namyśle krakowskiego filozofa szczególnie interesowała właśnie ta refleksja nad Innym. Tischner bardzo wcześnie jak na warunki polskie zetknął się z filozofią Lévinasa. W latach sześćdziesiatych minionego wieku przebywał na stypendium w Europie Zachodniej, gdzie swobodnie mógł studiować jego pisma. Później uczestniczył w wykładach badacza Talmudu i poznał go osobiście $^{33}$. Filozofia dialogu wywarła wtedy na nim tak ogromne wrażenie, że na jej podstawie ukształtował własne poglądy na temat relacji człowieka $z$ otaczajacym go światem i drugim człowiekiem. Kapuściński uważał, że wspólna Lévinasowi i Tischnerowi myśl wyszła od świadomości istnienia wyodrębnionego $z$ bezimiennej masy konkretnego Ja i konkretnego Innego. Dopiero $z$ potrzeby uogólnienia tego doświadczenia powstała filozofia dialogu ${ }^{34}$. W Myśleniu według wartości oraz późniejszej Filozofii dramatu Tischner zajął się problematyką człowieka i jego relacja $z$ Innym, zamiast problematyki ściśle ontologicznej, znajdujemy u niego radykalne zbliżenie do człowieka rozpatrywanego jednostkowo oraz sze-

32 Kłoczowski J. A., Filozofia dialogu..., s. 114.

33 Karoń- Ostrowska A., Spotkanie. Z ks. Józefem Tischnerem rozmawia Anna Karoń- Ostrowska, Kraków 2008, s. 75.

34 Kapuściński R., Ten Inny..., s. 55. rzej rozumianych zagadnień etycznych.

Kwestiami wybranymi przez Kapuścińskiego spośród bogatej spuścizny Józefa Tischnera, które chciałabym tutaj omówić sa filozofia dramatu, z obecnymi w niej pojęciami dialogu i spotkania. Punktem wyjścia tych dociekań musza stać się rozważania nad natura i treścia spotkania Ja $z$ Innym. Tischner podkreślał, iż spotkanie powinno być ważnym wydarzeniem, do którego należy się odpowiednio przygotować wewnętrznie ${ }^{35}$. Spotkanie według Józefa Tischnera powinno być dla nas przeżyciem niezwykle istotnym. Tak rozumiane spotkanie musi różnić się od obojętnego mijania się $\mathrm{w}$ anonimowym tłumie, które tak często w swoich utworach krytykował Kapuściński. Podróżnik podejrzewał, że przez napominanie nas, abyśmy w czasie spotkania $z$ Innym zachowywali świadomość wagi tej relacji, krakowski filozof chciał podnieść istotę i powagę stosunków międzyludzkich. Zależało mu na tym, byśmy zdawali sobie sprawe $z$ istoty i znaczenia relacji z Innymi.

Tragiczność oznacza, że każde dobro i wartość może ulec zniszczeniu przez zło lub antywartość. To samo dotyczy drugiego człowieka. Ludzkie obcowanie przenika tragizm, ponieważ każdemu spotkaniu grozi rozstanie, a każde rozstanie pamięta o spotkaniu. Niemożliwe jest radykalne odcięcie jednego od drugiego, co jest źródłem dążenia do powtarzania spotkań. Spotkanie nie musi kończyć się tragicznie, horyzont dramatu zakłada różne scenariusze, które sa jednakowo możliwe ze względu na hierarchiczność przestrzeni międzyludzkiej. Spotkanie oprócz dramatyzmu zakłada również dialog, którego celem ma być lepsze zrozumienie prowadzace do zbliżenia i zrozumienia osiaganego na drodze poznania.

35 Tamże, s. 55, 58 . 
Poznanie to Kapuściński rozumie jako chęć i zwrócenie się ku Innemu, wyjście $\mathrm{mu}$ naprzeciw i nawiazanie rozmowy ${ }^{36}$. W praktyce relacja taka okazuje się bardzo trudna.

W filozofii Lévinasa oraz Tischnera Kapuściński widział przede wszystkim nakierowanie na etykę, głęboki humanizm i heroizm występowania w obronie drugiego człowieka. Skromność, pokora oraz szacunek i poważanie wobec ludzi są zdaniem Kapuścińskiego niezbędnymi cechami dobrego reportera, który chce $z$ powodzeniem wykonywać swój zawód. Musi on zdawać sobie sprawę $z$ faktu, iż owoce jego pracy zależą $\mathrm{w}$ dużej mierze od tego, co inni dla niego zrobia, od tego co od nich usłyszy ${ }^{37}$. Tę życiową i zawodowa postawę Kapuściński przeniósł na grunt tworzonych przez siebie teorii. Spotkanie i rozmowa, a co za tym idzie porozumienie $z$ Innym miały odbywać się właśnie na gruncie etyki. Kontakt $z$ Innym na zasadach równości jest możliwy tylko $\mathrm{w}$ pełnym pokory nienaruszaniu jego prawa do odmienności ${ }^{38}$. Stosunek do Innego, o którym pisał Kapuściński, wymagał poszanowania, wrażliwości i uwagi.

Wiek XX okazał się cezura pomiędzy światem cywilizacji tradycyjnych, trwajacych stuleciami w niezmienionej formie, a ruchliwą społecznością współczesna, masowa, powoli już planetarna, odcięta od swoich korzeni, trwajaca w pospiesznej i nieustannej przemianie ${ }^{39}$. Szansa na zbudowanie solidnych podstaw koegzystencji w świecie jest według Ryszarda Kapuścińskiego dążenie do lepszego poznania innych kultur i ich mieszkań-

36 Tamże, s. 59. s. 54 .

37 Kapuściński R., Autoportret reportera...,

38 Kapuściński R., Dałem głos ubogim, Kraków 2008, s. 69.

39 Kapuściński R., Lapidarium IV...,, s. 37. ców, dialog i wola zrozumienia. Był przekonany, iż warunkiem współżycia ludzi różnych kultur i ras jest wzajemna znajomość i tolerancja. Porozumienie przez dialog nigdy nie było i nadal nie jest zadaniem łatwym ${ }^{40}$.

„Do spotkania trzeba sie więc wewnętrznie przygotować..."

\section{Bibliografia}

Chojnacka M. A., Problem odpowiedzialności $w$ filozofii Lévinasa, [w] Studia $z$ historii filozofii nr 2/2011.

Ciołek D. SJ; Oszajca W. SJ: W labiryncie kultur. Wywiad z Ryszardem Kapuścińskim, [w] Przegląd Powszechny nr $12 / 2004$.

Gadacz T., Filozofia Boga w XX wieku, Kraków 2007.

Golka M., Imiona wielokulturowości, Warszawa 2010.

Kapuściński R., Heban, Warszawa 2003.

Kapuściński R., Ten Inny, Warszawa 2006.

Kapuściński R., Lapidarium I-III, Warszawa 207.

Kapuściński R., Lapidarium VI, Warszawa 2007.

Kapuściński R., Lapidarium V, Warszawa 2007.

Kapuściński R., Rwacy nurt historii, Warszawa 2007.

Kapuściński R., Autoportret reportera, Warszawa 2007.

40 Tamże, s. 35.

41 Kapuściński R., Ten Inny..., s. 58. 
Kapuściński R., Dałem głos ubogim, Kraków 2008.

Karoń-Ostrowska A., Spotkanie. Z ks. Józefem Tischnerem rozmawia Anna Karoń-Ostrowska, Kraków 2008.

Kłoczowski J. A., Filozofia dialogu, Kraków 2005.

Levinas E., Odkrywajac egzystencje Husserlem i Heideggerem, Warszawa 2008.

Lévinas E., Inaczej niż być lub ponad istota, Warszawa 2000.

Savidan P., Wielokulturowość, Warszawa 2012.
Skarga B., Lévinas E. - metafizyka jako etyka, [w] Filozofia XX wieku. Tom I, Warszawa 2002.

Tischner J., Myślenie według wartości, Kraków 2011.

Walczak B., Antropolog jako Inny, Warszawa 2009.

Waligóra M., Etyczny projekt Emmanuela Lévinasa - fenomenologia czy antyfenomenologia?, [w] Fenomenologia nr 6/ 2008. 